\title{
French appeal court sends Allain to jail
}

Paris. Two former officials of the French National Centre for Blood Transfusion (CNTS), Michel Garretta and Jean-Pierre Allain, last week lost their appeals against four-year prison sentences. They were convicted last ycar of consciously allowing haemophiliacs to be treated in 1985 with clotting factors contaminated with HIV when a heat-inactivated alternative was available.

The appeals court upheld the four-year sentence for Garretta, former director-general of CNTS. It reaffirmed that he knew CNTS clotting factors were contaminated and that one-tenth of haemophiliacs treated would die of AIDS within five years and that he continued to supply contaminated clotting-factors "while stocks last" for financial reasons, instead of importing heat-inactivated preparations. (CNTS had a monopoly for the import of blood products into France.)

The court also upheld the four-year sentence (with two years suspended) for Allain, former head of research and development at CNTS. It convicted him, as a "specialist of haemophiliacs", for not telling haemophiliacs that all stocks were probably contaminated, for being at the meetings at which CNTS chose to supply unheated clotting factors "while stocks last" and for continuing clinical trials of untreated products after he knew of the danger.

Robert Netter, former head of the National Health Laboratory, who was previously acquitted, was given a one-year suspended sentence. Jacques Roux, former director-general of health at the National Ministry of Health, had his four-year suspended sentence reduced to three.

Olivier Schnerb, the lawyer representing Allain, says it is "abnormal" that the appeals court should have convicted Allain on "new grounds" after having rejected those on which he was first convicted: that he was present at the meeting in May 1985 which decided to delay introduction of heat-treated products for five months. Schnerb will fight the verdict in the Supreme Court of Appeals.

Schnerb now alleges that the trial was a "decoy" to "appease public opinion" and to detract attention from another "bigger scandal": that a deliberate delay - this time in screening blood donors for HIV - exposed the wider public to risk of HIV infections from transfusions with contaminated whole blood. This affair has been hushed up, he claims, because it could "implicate former ministers, and their chief scientific advisers". Government officials are alleged to have deliberately delayed approval of a US AIDS test for five months in 1985 so that a test developed by Diagnostic Pasteur could be released first (see Nature 353, 197; 1991).

"It's so damn obvious that this question comes next," says Jacques Liebowitch, of the Raymond Poincaré Hospital near Paris, "it's amazing it didn't come up before." More than 9,000 people were infected with HIV in France following transfusion with contaminated whole blood, he says, many during the five-month delay before France began systematically screening donors.

Using a prototype indirect immunofluorescence AIDS test, Liebowitch and François Pinon of Cochin Hospital in Paris discovered in December 1984 that one in every 200 blood donors in Paris was seropositive. "We said that donors needed to be screened immediately," he claims, "but there was a plot to play down the risk of blood contamination and the pathogenicity of the virus, because of the alternative Abbott (US) test ... this propaganda was spread right up to the level of the prime minister

. it was passive mass murder."

One reason why infection by whole blood transfusions has attracted little attention is that individuals have not called for criminal proceedings: most have settled for compensation of several million francs. Judicial proceedings were begun in the clotting factors case only after persistent efforts by the well organized haemophiliac groups.

"Protected" individuals have escaped justice, Schnerb says. He claims that this also explains why Allain was originally tried in a magistrate's court on the trivial charge of deception over product quality: "They wanted a scapegoat, but keep clear consciences by giving him a short sentence."
Judicial reform

Meeting last Monday (19 July) at the Palace of Versailles outside Paris, for only the fifth time since the birth of the Fifth Republic in 1958, the French Parliament voted for changes to the constitution - a reform of the High Court of Justice - that could speed up the prosecution of former ministers allegedly involved in the blood contamination scandal.

Previously, current and former cabinet officials could be judged only by the High Court of Justice, and only if the charges were brought by a member of parliament: the court was never convened during the Fifth Republic. Clamour for change began last year, following the failure of repeated attempts to try three Socialists in power at the time of the blood scandal former prime minister Laurent Fabius, the former deputy health minister Edmond Herve and the former social affairs minister Georgina Dufoix.

The key change is that anyone can now bring charges against current or former ministers. These would be judged not by the High Court but by a newly created lower court, the 'Court of Justice of the Republic'. The High Court will now exist only to judge the president for high treason.

D.B.

He also argues that Allain should have been tried in a criminal court, where it would have been necessary to decide whether he was "innocent or guilty". "Only four years for a death! That's stupid. It should be either a life sentence or acquittal."

Declan Butler

\section{Fight to relax German research curbs}

Münster. The Deutsche Forschungsgemeinschaft (DFG), Germany's major sponsor of basic research, plans openly to fight back against the public hostility directed against German researchers, which it believes is not found elsewhere in Europe.

At DFG's annual meeting earlier this month, it was decided to establish a working group specifically aimed at countering "obstructions to research". The initiative is the first of its kind in Europe.

President Wolfgang Frühwald told the gathering that it is "high time to challenge the infectious spread of anti-scientific sentiment in Germany", to which he partly attributes Germany's falling international competitiveness in some fields, notably in information technology and biotechnology.

The working group will take on all issues that impede research, particularly in the areas of genetic engineering, data exchange, embryo research and animal experimentation, where legislative "safeguards" consid- ered over-stringent cause researchers to abandon the bureaucratic battle - and their experiments. For example, Germany's gene law (which may be somewhat relaxed before the end of the year) has made it almost impossible to do any experiment at all that involves gene manipulation (see Nature 363, 481 ; 1993). DFG fears that these frustrations could drive promising young researchers abroad.

The new working group probably will be headed by Rüdiger Wolfrum, DFG board member and director of the Max Planck Institute for Comparative Public Law at Heidelberg. The composition and workplan of the group has not yet been defined, but DFG hopes that other research organizations in Germany, such as the Max Planck Society and the organization for the national research centres, will eventually join in.

Robert Unterhuber

“Germany's tight budget", page 273 